\title{
Male breast cancer: a rare case of neoplasia in elderly; our experience and review of the literature
}

\author{
Stefano Reggio ${ }^{*}$, Luciano Grimaldi, Mario Pannullo, Marco Ferretti, Rita Compagna, Bruno Amato, Michele Danzi \\ From 26th National Congress of the Italian Society of Geriatric Surgery \\ Naples, Italy. 19-22 June 2013
}

\section{Background}

Male breast cancer $(\mathrm{MBC})$ is a rare tumor and accounts for $<1 \%$ of all breast cancers, but its incidence is increasing. The majority of breast lesions in men are benign and the causes, optimal treatments, and medical/ psychosocial sequelae of breast cancer in men are poorly understood. [1] The natural history and prognostic factors do not differ from the female form, this tumor is characterized by a higher mortality rate because the presenting symptoms are often underestimated, and it comes to diagnosis when the disease is already advanced [2].

\section{Methods}

In our study we retrospectively analyzed the clinicopathologic features and prognosis of 16 cases of male breast cancer diagnosed in our hospital from 1998 to 2010, and we assessed whether prognostic factors in male (MBC) and female (FBC) breast cancer have similar impact on survival: the aim of our study was to compare overall survival (OS) and disease-free survival (DFS) in a group of matched males and females with breast cancer with similar prognostic factors (including age, nodal status, resection margin, use of hormonal therapy, chemotherapy with/without hormone and radiation therapy).

\section{Results}

Matching was conducted based on age, year of diagnosis, stage of the disease and pathology. The mean age at

\footnotetext{
* Correspondence: sterex@fastwebnet.it

Department of Specialized Surgery, Division of Gastrointestinal Surgery Rehabilitation of Election and Emergency. "Federico II" University, Naples, Italy
}

C 2013 Reggio et al; licensee BioMed Central Ltd. This is an Open Access article distributed under the terms of the Creative Commons Attribution License (http://creativecommons.org/licenses/by/2.0), which permits unrestricted use, distribution, and reproduction in any medium, provided the original work is properly cited. diagnosis was $60.0 \pm 11.3$ years for males and $56.1 \pm 10.6$ years for females, and the median follow-up time was 54 months (range, 5-242 months) for males and 60 months (range, 29-263 months) for females. The invasive ductal carcinoma in $\mathrm{MBC}$ was much higher than in $\mathrm{FBC}$. The positive rate of estrogen receptors in $\mathrm{MBC}$ patients was higher than in FBC patients $(\mathrm{P}=0.048)$, whereas HER-2 was positive in $13.8 \%$ of $\mathrm{MBC}$ patients, which was significantly lower than in FBC patients $(\mathrm{P}=0.001)$; HER2-positive patients had a statistically worse prognosis than HER-2-negative patients $(\mathrm{P}=0.040)$. The overall survival rates of $M B C$ were significantly higher than FBC. Lymph node metastases and larger tumor size were also associated with poorer prognosis. Not statistically significant differences were identified for tumor location between the two groups.

\section{Conclusions}

BRCA2 mutations, lower age, lymph nodes metastases and tumor size are proven risk factors. The FBC patients were significantly different from the $M B C$ in clinicopathologic and prognostic characteristics: the HER-2 positivity, much higher in women, was an important factor for bad prognosis [3,4] . Disease biology is distinct in men, but diagnostic approaches and treatments for men are generally extrapolated from those in women due to inadequate research in men.

\section{Published: 16 September 2013}

\section{References}

1. Ruddy KJ, Winer EP: Male breast cancer: risk factors, biology, diagnosis, treatment, and survivorship. Ann Oncol 2013.

2. Serra $R$, Buffone $G$, Perri $P$, Renne $M$, Amato $B$, de Franciscis $S$ : Male breast cancer manifesting as Cephalic Vein Thrombosis in a 70-year-old patient. Ann Vasc Surg 2013.

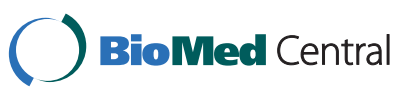


3. Baojiang L, Tingting L, Gang L, Li Z: Male breast cancer: A retrospective study comparing survival with female breast cancer. Oncol Lett 2012, 4(4):642-646, Epub 2012 Jul 18.

4. Amato B, Rispoli C, lannone L, Testa S, Compagna R, Rocco N: Surgical margins of resection for breast cancer: Current evidence. Minerva Chirurgica 2012, 67(5):445-452.

doi:10.1186/1471-2482-13-S1-A39

Cite this article as: Reggio et al.: Male breast cancer: a rare case of neoplasia in elderly; our experience and review of the literature. $B M C$ Surgery 2013 13(Suppl 1):A39.

Submit your next manuscript to BioMed Central and take full advantage of:

- Convenient online submission

- Thorough peer review

- No space constraints or color figure charges

- Immediate publication on acceptance

- Inclusion in PubMed, CAS, Scopus and Google Scholar

- Research which is freely available for redistribution

Submit your manuscript at www.biomedcentral.com/submit
() Biomed Central 